\title{
The Image of the Fragile Ashienazi JeW
}

\author{
Miri Freilich \\ (Yad Vashem and Haifa University) \\ e-mail: mirifreilich@gmail.com
}

Keywords: Alona Frankel, Amos Oz, Ashkenazi Jews, David Grossman, diaspora Jews, Gila Almagor, Holocaust survivors, immigrants, Israel, Mapai, Midrasha Gallery, Mizrachi Jews, second generation, "Sabra," Yechazkel Rahamim, Zionism

\begin{abstract}
The article examines the various presentations of Ashkenazi Jews in Israeli fiction. Ashkenazi identity in Israel is controversial both in everyday life and in fiction. However, the literary and artistic manifestations of Ashkenazi Jews are quite different from their political and social image. Ashkenazi Jews are usually portrayed as the intellectual, economic, and professional elite, and also as those who were responsible for the inequality between Jews who immigrated to Israel from Europe and Jews from Arabic countries. They are depicted by the Israeli media as those who forced the oriental Jews to settle in remote towns in Israel, thus denying them the ability to move up the social ladder.

The arrogant, upper-middle-class Ashkenazi is often absent from Israeli literature. Israeli artists of Ashkenazi origin present themselves in autobiographical literature as "weak" or "problematic" and they add a "fragile" aspect to the Ashkenazi identity. The Ashkenazi Jew is depicted as an insecure figure who agonizes over fears and childhood traumas. The image of the "fragile Ashkenazi," appears in some of the most prominent Israeli writing: Amos Oz's A Tale of Love and Darkness, David Grossman's A Horse Walks into a Bar, and Gila Almagor's book and film Avia's Summer.
\end{abstract}

Ashkenazi Jews in Israel, immigrants and descendants of European Jews, are the largest ethnic group of Israel's population. ${ }^{1}$ They are sometimes portrayed in the media as an elite group that dominates the judicial system, economics, universities, and the intellectual elite in Israel. ${ }^{2}$

Ashkenazi Jews are often described as an ethnic group that exploited immigrants of Mizrachi origin, Jews who immigrated from Arab and Muslim countries and their descendants in the early years of the State of Israel. A documentary ${ }^{3}$ based on detailed research recently screened on Israeli public broadcast TV reveals how the Ashkenazi leadership took advantage of these immigrants during the large waves of immigration between 1948 and 1963. The documentary, entitled The Ancestral Sin (Salach Po Ze Eretz Israel), shows the methods used to forcibly settle in Israel new immigrants from

\footnotetext{
${ }^{1}$ Statistical Abstract of Israel, (2018). Table 2.24 - Jews, by country of origin and age, 2017.

2 Shabi 2008.

${ }^{3}$ Deri 2017.
} 
Muslim countries, primarily in North Africa, to isolated and desolate development towns in the Negev in the 1950s. These towns were constructed hastily and offered little to their inhabitants socially or economically. The process was accompanied by lies, trickery, condescension, and outright racism on the part of the Jewish Agency's Ashkenazi leadership and the settlement authorities of Mapai, the ruling party of the State of Israel. ${ }^{4}$

The negative characteristics of the Ashkenazi Jews as an elite group were presented in an exhibition entitled The Ashkenazim at the Midrasha Gallery in Tel Aviv several years ago. ${ }^{5}$ Ashkenazi Jews were portrayed as aggressive and cruel. The works of art presented there provoked angry reactions, especially from Holocaust survivors and their descendants. The idea that Jews of Ashkenazi origin were portrayed in such manner was hard to accept. However, in contrast to the exhibits in the gallery and David Deri's film, entirely different characteristics of Ashkenazi Jews in Israel are portrayed in contemporary literary works. Several famous native Israeli writers and second-generation Holocaust writers also attached weak and problematic aspects to the characters of Ashkenazi literary heroes. The image of the Ashkenazi in modern Israeli literature is quite different.

In some of the most famous literary works of David Grossman, Amos Oz, and others, Ashkenazi Jews often appear as weak, hesitant, and tormented characters. Some of these writers refer to their real childhood, while others to an imaginary literary one. ${ }^{6}$ They describe a painful process of growing up, often as outsiders who were unable to integrate into the society of children, or that of adults. These characteristics raise questions as to the purpose of portraying them as helpless or tormented characters. Why do Amos Oz's A Tale of Love and Darkness (2002), David Grossman's A Horse Walks into a Bar (2014), and Gila Almagor's famous book (1985) and film (1988) The Summer of Aviya feature fragile children?

A Tale of Love and Darkness ${ }^{7}$ is the story of Oz's youth. He was born in Jerusalem at the outbreak of the Second World War, a lonely, only child gifted with a rich imagination. His father Yehuda was a learned and self-educated librarian who studied history and literature and aspired to become a professor of Comparative Literature. He was a close relative of Josef Klausner (1874-1958), a historian and professor of Hebrew literature. ${ }^{8}$ He was the chief editor of the Encyclopedia Hebraica and a candidate for President in Israel's first presidential election in 1949. ${ }^{9}$ For various reasons, Oz's father was unable to integrate into the narrow and competitive academic world of Israel in the 1950s

4 35,000 immigrants came to Israel from Morocco in the years following the founding of the state, particularly in 1954-1955. The mass immigration ended when Morocco gained independence from France in 1956. In total a quarter of a million people moved to Israel from Morocco, becoming the largest group of immigrants from an Arabic country.

Most of the newcomers from North Africa were housed in transit camps in development towns on Israel's periphery. Many immigrants were forced to leave their properties and wealth behind and suffered a severe decrease in their socioeconomic status, aggravated by an austerity policy in place in Israel at the time. They were looked down on by the country's decision-makers, who were mainly of European origin. See also Cohen 2002, Lipson 2015, Stuff 2018.

5 The Ashkenazi Jews, an exhibition (2008) www.rutidirektor.wordpress.com.

${ }^{6}$ Other prominent writers who wrote on this issue but were not mentioned in this essay are: Nava Semel, Lili Peri, Lizi Doron. See Milner 2003.

7 Oz 2002.

8 Ibid.: 18-19.

9 Ibid.: 46-86 
and 1960s. Oz's mother, Fanya, was an educated young woman from a wealthy Polish Jewish family who immigrated to Palestine. Oz's parents were multilingual; his father claimed that he could read sixteen or seventeen languages, while his mother spoke four or five languages, and could read seven or eight. Neither of his parents was comfortable speaking Hebrew. They spoke Russian or Polish to each other, while the only language they allowed $\mathrm{Oz}$ to learn was Hebrew. ${ }^{10}$

Fanya studied at the Hebrew University of Jerusalem and was among the few female students there at the time. Owing to her mental illness, she committed suicide in 1952 , one month before Oz's bar mitzvah ceremony. When Oz was fourteen, his father remarried and the boy left home to join a kibbutz. He was determined to leave his gloomy background behind and become a confident young man by becoming a kibbutz member. He wished to change his nature from a fearful, pale, and morose boy to become a tanned and physically strong young man like his classmates on the kibbutz. He even changed his last name from Klausner to Oz, which means strength in Hebrew, thus causing his father grief. ${ }^{11}$

Picasso's painting The Tragedy (1903) appears on the cover of Oz's book. The painting portrays the hunched and somber figures of a young man, woman, and child in gloomy blue shades. Oz's early childhood was indeed sad and tragic, overshadowed by his mother's mental illness. The dismal atmosphere in his home and his loneliness are central to the book. Kerem Avraham, his Jerusalem neighborhood, was both cheerless and desolate. The misery that surrounded his parents' lives characterized his neighbors as well. "Zelda, the teacher, the Krochmal couple, and others were hardworking people who dreamed of being anything else than what they were. The neighborhood portrayed lost ideals, fears, and despair."12

$\mathrm{Oz}$ describes his loneliness and physical weakness as a child in school as well. He studied at a school in which most children immigrated from Muslim countries. The children came from poor families and their parents were uneducated artisans and shopkeepers with eight or ten brothers and sisters per family. Oz was the only child at the school with no siblings: "They harassed me by the water fountain in the schoolyard, spraying water on me." The boys quickly discovered that he was "the weakest of them all and easily insulted and inclined to be hurt with every push or insult."13

The fragile boy in Oz's book is quite like another literary character, a nameless child in a story entitled Our Ashkenazi Boy (2004) by a young and lesser known writer Yechazkel Rahamim. The boy in Rahamim's story is helpless, thin, and pale, like Oz's literary hero. He is the only Ashkenazi child at a boarding school of violent and aggressive Mizrachi boys. Every day, the Ashkenazi boy has to face a group of violent children. $\mathrm{He}$ is frequently beaten and becomes the scapegoat of the group. When the TV in the dining room of the school breaks down, the kids force the Ashkenazi child to confess to an offense he did not commit.

The literary hero of Gila Almagor's famous book, The Summer of Aviya (1985), is a fragile and lonely girl. Almagor describes a daughter of a Holocaust survivor

\footnotetext{
10 Ibid.: 2, 180.

11 Ibid:: 102-103.

12 Ibid.: 20-21, 546.

13 Ibid.: 436.
} 
who is taunted by the native Israeli children, or Sabras in Hebrew, in her neighborhood. The book and film chronicle the life of ten-year-old Aviya and her mother Henya, a Holocaust survivor. Henya's psychological and emotional problems stem from her experiences during the Holocaust and from the loss of her husband during the war. Aviya and her mentally ill mother are confronted and mocked by the children of their neighborhood. Aviya is portrayed as a girl with a vivid imagination. She hopes that her mother's problems will be solved if she succeeds in finding her father. Aviya is a peculiar and vulnerable girl and thus becomes the scapegoat of the children in the neighborhood. Aviya invites children to her birthday party which her mother prepares for her, but none of them show up. The cruel attitude of the children towards her and the abusiveness of her mother cause Aviya to become violent. One of the most heart-breaking scenes in the film is when the mother shaves her daughter's head, making her bald because she believes that her daughter has lice in her hair and needs to be disinfected. Aviya's bald head makes her even lonelier. The film and book are autobiographical; Almagor was born four months after the death of her father, a Jewish policeman who immigrated from Germany and was killed by an Arab sniper while on duty in Haifa. Almagor grew up caring for her mother, Chaya, who was slowly losing her sanity after realizing that her whole family in Germany had perished in the Holocaust. When her mother was institutionalized in 1954, Almagor was sent to Hadassim Youth Village. ${ }^{14}$

The world-famous author David Grossman also portrays troubled and fragile children in his books. On Israel's 70th Independence Day, Grossman received the important Israel Prize for his literary achievements. He won the Man Booker International Prize, one of the most prestigious literary awards in the world, for his novel A Horse Walks into a Bar in 2017.

Grossman deals extensively with the impact of the Holocaust on Israeli society in his fiction. In three of his famous books, See Under: Love, The Book of Internal Grammar, and A Horse Walks into a Bar, he portrays children of Holocaust survivors, fragile and frightened children. In See Under: Love, Momik is a young son of Holocaust survivors. His parents have never told him what really happened to them "over there" in Europe during the Holocaust. The frightened Momik, who has heard them talking about the "Nazi Beast"15 imagines it as a monster that rules a land called "Over There," where it tortured the people Momik loves. The monster has damaged them forever and denied them the ability to live a full life.

Grossman explains that he chose to portray Momik, his literary hero, as a frightened and insecure child because of his own personal experiences as a child:

When I was four or five, I heard of Simon Wiesenthal, the Nazi-hunter, for the first time. I felt a great sense of relief; finally, I thought, there is someone courageous enough to fight the beast, even willing to hunt it down! ${ }^{16}$

However, Grossman is not a son of Holocaust survivors; his father immigrated to Palestine from Poland as a child in 1936 and his mother was born in Palestine, before the State of Israel was established. Although Grossman is a native Israeli, when he published

\footnotetext{
14 Almagor 2010.

15 Grossman 1986: 17.

16 Grossman 2007.
} 
See Under: Love in Israel, some critics mistakenly identified him as the son of Holocaust survivors. ${ }^{17}$

Even though Grossman is a native Israeli, he admits to sometimes feeling like a son of a Holocaust survivor. As in so many Israeli homes "[...] a thread of deep anxiety and insecurity prevailed" in his home as well. ${ }^{18}$ The Holocaust was present in his life as a young boy. He remembered how his parents attended the Eichmann trial and would talk about the Holocaust at home.

His latest book, A Horse Walks into a Bar, is also about a family of Holocaust survivors. ${ }^{19}$ The book centers on a comedian who grew up as an only child of Holocaust survivors. He delivers a stand-up performance in a godforsaken bar in the industrial area of Netanya, a small coastal Israeli town. The book begins with the comedian making jokes, but he ends up talking at length about his troubled childhood while his audience slowly leaves the bar. The comedian, Dovaleh Greenstein (his initials DG are the same as Grossman's) tells the crowd about his personal problems. He is paying alimony to three ex-wives and supports five children. During his performance, Dovaleh quickly wins over the crowd by targeting certain guests and using vulgar humor, but as the night wears on, Dovaleh begins sharing sad stories of his childhood and making fewer jokes, until he eventually loses the entire crowd. The narrator telling the story is a childhood friend of Dovaleh. He was invited by Dovaleh to the performance, and he realizes halfway through the performance, based on his appearance, that Dovaleh is dying of what is probably cancer. Dovaleh's exaggerated and infectious full-bodied belly laugh is a symbol of his desire to be laughing with his friend, rather than be laughed at. His desire to mock others began at a camp with his school mates where he willingly became the other boys' target of teasing. While at camp, he was notified that one of his parents had died, but no one could tell him that it was his mother. He preferred that it be his father, who used to beat him for trying to make his depressed mother laugh by walking on his hands. $\mathrm{He}$ feels better when the driver who was to take him back home to the funeral tells Dovaleh an adult joke, which helps him temporarily forget about the grief of the funeral awaiting him. As in Oz's biography, Dovaleh's mother had committed suicide, but he only finds out about it when he arrives home.

Unlike the authors discussed above, Alona Frankel, (b. 1937), is a well-known children's author and Holocaust survivor who immigrated to Israel in 1949 as a child. She published thirty very popular children's books, many of which were translated to various languages. She also wrote two books for adults about her experiences as a child during the Holocaust and her first years as a young immigrant in Israel. She wrote about the intolerant attitude of the Israeli children and adolescents towards her.

Born in Kraków, she was separated from her parents when the Kraków ghetto was established. Frankel was raised by an elderly woman who was paid by her parents to hide her. She was transferred to an orphanage at the end of the war because her mother suffered from tuberculosis and was too ill to take care of her. When her mother recovered, the family immigrated to Israel along with a hundred Holocaust survivors. ${ }^{20}$ When

\footnotetext{
17 Ibid.

18 Ibid.

19 Grossman 2014.

20 Frankel 2004.
} 
their ship anchored at Haifa Port, many of them were seasick and exhausted. Her first encounter with young native Israelis, Sabras, was when they came on the ship's deck to welcome the immigrants to the Land of Israel. She immediately noticed that they were different, "They were beautiful, tanned, and healthy looking [...] They threw oranges to the crowded, exhausted and worried people, the new immigrants from Poland." ${ }^{21}$ This humiliated Frankel since it seemed to her that they were acting as though they were superior to the immigrants on the ship. "It was so cold on the ship... [and] there was an odious smell of vomit, Polish sausage, and oranges..." 22 She refrained from bending down to pick up the oranges that fell on the deck because, in contrast to the other literary figures of Oz, Almagor, Grossman, and Rahamim, she did not feel fragile or anxious even though she was a survivor. She was too proud to bend down and pick up the oranges thrown at her because she did not want to feel patronized by the arrogant young Israelis.

In her second autobiographical book, Teen Years she criticizes the negative attitude of children and adults towards her. ${ }^{23}$ Frankel's autobiographical books are an example of the concluding remarks of Estranged Brothers by Hanna Yablonka in which she claims that Holocaust survivors were regarded as people who were incapable of being productive or contributing to building the new Jewish State. ${ }^{24}$ Despite this negative attitude, many of them rehabilitated themselves and became absorbed into Israeli society. Against all odds, the survivors of the Holocaust and their offspring became pillars of modern Israeli society. ${ }^{25}$ The remaining question is why did the native Israeli writers discussed here, those who were not Holocaust survivors or second-generation survivors, portray their literary characters as frail and fragile? Besides their literary intentions, one can reach additional conclusions as to the need to describe weak and helpless characters: In his speech on Israel's 70th Memorial Day, Grossman emphasized that although Israel had become a powerful country and won numerous battles against its enemies, it is more of a fortress than a home:

Home is a place whose walls - borders - are clear and accepted; whose existence is stable, solid, and relaxed; whose inhabitants know its intimate codes; whose relations with its neighbors have been settled. It projects a sense of the future. And now, 70 years later, strong Israel may be a fortress, but it is not yet a home. We Israelis, even after 70 years - no matter how many words dripping with patriotic honey are uttered in the coming days - we are not yet there. We are not yet home. Israel was established so that the Jewish people, who have almost never felt at home in the world, would finally have a home. And now, 70 years later, that strong Israel may be a fortress, but it is not yet a home. ${ }^{26}$

Grossman stressed the fragility of Jewish existence throughout the ages:

I think the deep definition of the Jew as an individual, and as a collective, throughout our history, was of someone who never really felt at home in the world. We never really had a place that was like home, except for some periods in the distant past. And Israel is meant to be this home. It's a home that is worth fighting for. I think the tragedy is that even though we are

\footnotetext{
${ }^{21}$ Ibid.: 247.

22 Ibid.

23 Frankel 2009.

24 Yablonka 1994: 261.

25 Milner 2003: 62-64.

26 Grossman 2018.
} 
celebrating - and it's really a reason to celebrate, the 70th anniversary of Israel - still it is not a real home... I don't want to live in a fortress. I want to live in a home. ${ }^{27}$

It is possible that Israeli writers felt the need to portray fragile people as individuals even though they are protected in their "fortress." Thus, Grossman's fiction analysed here attempts to add an additional dimension to the identity of the safe and self-confident Ashkenazi Jews in Israeli society.

The image of the fragile Ashkenazi anti-hero is associated with the negative image of the Diaspora Jew, condemned and rejected by the founders of the Zionist movement in Eastern Europe. The Diaspora Jew, living in fear in his surroundings, contrasts with the image of the tanned, strong, and self-assured native Israeli. Zionism aimed to encourage the frail and frightened Jews to leave their country of birth, rebel against this self-image, and immigrate to Israel to become self-assured and protected.

Ashkenazi Jews who immigrated to the Land of Israel before the outbreak of the Second World War and after the establishment of the state aspired to change and create a new identity, that of the Sabra. ${ }^{28}$ Rejecting life in exile went hand in hand with encouraging the uprooting of the Diaspora Jew from his immediate surroundings. Yet, according to literary and real portraits discussed here, Zionist ideology was unable to erase the insecurities and the weaknesses of Ashkenazi Jews. Amos Oz wrote explicitly about his unsuccessful attempts to erase his past by acquiring a tanned skin and becoming a farmer on Kibbutz Hulda. He remained the dreamy and sensitive person of his childhood in Jerusalem. Although his aspiration to become a writer never waned, he continued to bear his fragile and insecure characteristics. ${ }^{29}$ Ashkenazi Jews born in Israel aspired to fulfil the image created by the Zionist movement. However, they all bore the fragility of the Diaspora Jew.

Thus, Ashkenazi Jews in Israel do not have only one facet. Israeli writers shattered their image and presented them as the diverse and complex characters that they really are.

\section{BIBLIOGRAPHY}

Almagor, G. (1985), Hakaitz Shel Aviya [The Summer of Aviya], Tel Aviv.

Almagor, G. (2010), Kochavim Yesh Rak Bashamayim [Stars are Only in Heaven], Tel Aviv.

Cohen, E. (2002), The Moroccan Jews, The Negative of the Ashkenazi Jews, Tel Aviv.

Cohen, J. (1990), Voices of Israel: Essays on and Interviews with Yehuda Amichai, A. B. Yehoshua, T. Carmi, Aharon Appelfeld, and Amos $\mathrm{Oz}$, New York.

Deri, D. (Director) (2017), The Ancestral Sin [Salach, Po Ze Eretz Israel], https://www.imdb.com/title/ tt7193882.

Frankel, A. (2004), Yalda [A Girl], Tel Aviv.

Frankel, A. (2009), Naara [Teen Years], Tel Aviv.

Grossman, D. (1986), Ayen Erech Ahava [See Under: Love], Tel Aviv.

Grossman, D. (1991), Sefer hadikduk hapnimi [The Book of Internal Grammar], Tel Aviv.

\footnotetext{
27 Ibid.

28 See Oz 1997; Schwartz, Sapir 2014.

29 Oz 2002: 570.
} 
Grossman, D. (2007), Confronting the Beast, at: https://www.theguardian.com/books/2007/sep/15/ featuresreviews.guardianreview2.

Grossman, D. (2014), Sus Echad Nichnas le Bar [A Horse Walks into a Bar], Tel Aviv.

Grossman, D. (2018), Israel is Less a Home, at: https://www.haaretz.com/israel-news/fulltext-speechby-david-grossman-at-alternative-memorial-day-event-1.6011820.

Lipson, J. (2015), Ashkenazi Revolution: The Politics of Reaction, Heresy, and Suppression in 1960s Israel, Cambridge, MA.

Milner, I. (2003), Kiray avar [Past Present: Biography, Identity and Memory in Second Generation Literature], Tel Aviv (in Hebrew).

Oz, A. (1997), Hatzabar - Diyokan [The Sabra - a Portrait], Tel Aviv.

Oz, A. (2002), Sipur al Ahava VaChoshech [A Tale of Love and Darkness], Tel Aviv.

Rahamim, Y. (2004), Ha'ashkenazi Shelanu [Our Ashkenazi Boy], at: https://www.haaretz.co.il/literature/1.958222.

Schwartz, Y., Sapir, M. (2014), The Zionist Paradox: Hebrew Literature and Israeli Identity, Waltham.

Shabi, R. (2008), We Look Like the Enemy: The Hidden Story of Israel's Jews from Arab Lands, New York.

Stuff, T. (2018), Amid Racism claims, state to open archives on Jewish North African immigration, Times of Israel, at: https://www.timesofisrael.com/amid-racism-claims-state-to-openarchives-onjewish-north-african-immigration.

Yablonka, H. (1994), Ahim Zarim [Alien Brethren, Survivors of the Holocaust: Israel After the War], Jerusalem. 